\title{
Sustainable Dyeing of Cotton Fabric Using Black Carrot (Daucus carota L.) Plant Residue as a Source of Natural Colorant
}

\author{
Fatima Batool ${ }^{1}$, Naeem Iqbal ${ }^{1 *}$, Muhammad Azeem ${ }^{1}$, \\ Shahid Adeel' ${ }^{2}$ Muhammad Ali $^{3}$ \\ ${ }^{1}$ Department of Botany, Government College University Faisalabad, Pakistan \\ ${ }^{2}$ Department of Applied Chemistry, Government College University Faisalabad, Pakistan \\ ${ }^{3}$ Department of Zoology, Government College University Faisalabad, Pakistan
}

Received: 13 June 2018

Accepted: 23 July 2018

\begin{abstract}
Rising environmental concerns toward the use of synthetic chemicals as well as global acceptance of natural products has emphasized the need for exploring novel and sustainable sources of eco-friendly dyes for the textile sector. Our study was conducted to explore the natural colorant potential of black carrot (Daucus carota L.) plant residue for textile processing and optimizing conditions for cotton dyeing. Cotton fabric was dyed using black carrot-based dye, extracted in varying media. The results revealed that black carrot colorants produced darker shades when extracted in acidified methanol media. Excellent color strength of cotton fabrics were found at $70^{\circ} \mathrm{C}$ by coloring for 55 minutes using $4.0 \mathrm{~g}$ of salt $(\mathrm{NaCl})$ as an exhausting agent. The bio mordants as well as chemical mordant were employed to improve color strength properties. In the case of chemical mordanting, $6 \%$ tannic acid and $8 \%$ iron sulphate as pre-mordant and $8 \%$ tannic acid and $2 \%$ iron sulphate as post-mordant showed maximum color strength values. Similarly, using bio mordanting, $2 \%$ of turmeric (Curcuma longa L.) and $6 \%$ of henna (Lawsonia inermis L.) extracts as pre-mordant, as well as $8 \%$ of turmeric and $4 \%$ of henna extracts as post-mordant showed maximum color strength values. Dyed cotton fabrics exhibited best color fastness properties in term of light, washing, dry and wet rubbing fastness.
\end{abstract}

Keywords: black carrot, color fastness, color strength, cotton fabric, mordanting

\section{Introduction}

Humanity has been blessed by nature with brilliant and eye-catching colors of eco-friendly origin [1-2].

*e-mail:drnaeem@gcuf.edu.pk

These natural gifts of colors have always been used by humans to dye clothing and other items. A considerable decline in the utilization of natural colorants has been observed since the discovery of the first synthetic dye [3-4]. There is an increasing awareness that natural dyes are a good alternative to synthetic dyes due to their biodegradability and sustainability, as well as soothing nature [7-8]. Hence, the demands for 
eco-friendly natural colorants have risen again around the globe due to increasing health hazards associated with the use of synthetic dyes [5-6].

The color strength and shades of dyes derived from different natural sources depends on the nature of extraction media as well as dyeing conditions [9-11]. Finding optimum extraction and dyeing conditions is the pre-requisite for natural dyes to be used in coloring of food substrate, leather, wood, plastics, paints and pharmaceutical products [12-13]. Different parts of plants such as the outer shell of bulbs [14], flowers [15], fruit peels [16], barks [17] and vegetative organs [18-19] are being used to extract natural dyes for textile processing. While using the natural source of colorants, the trimmed and surplus plant material has been gaining considerable attention from researchers and consumers over the last decade [18-20]. This is a sustainable approach because utilization of leftover plant material in natural dye extraction does not disturb ecological balance and biodiversity.

Black carrot (Daucus carota L.), the root vegetable belonging to the Apiaceae family, is cultivated all around the world [21]. Carrots are a rich source of different active photochemicals such as phenolics, flavonoids, carotenoids, chlorophylls and anthocyanins [22-23]. The darker color of black carrot is due to the presence of anthocyanin [24-25], which are mainly distributed among flowers, fruits and vegetative parts and impart bright colors such as purple, red and blue to these plant organs [26-27]. These have antioxidant [28], anti-fungal, anti-bacterial and anti-cancerous properties [29], and are widely used in food, drugs and in pharmaceutical products [30].

The present investigation is an attempt to utilize black carrot that is left over from extracting natural colorant for cotton dyeing. The objective of the current study is to provide a cheap and ecofriendly source of dye for the textile industry as well as characterize natural colorants obtained from black carrot leftovers.

\section{Material and Methods}

Black carrot (Daucus carota L.) leaves were collected from the Vegetable Research Institute, AARI, Faisalabad, Pakistan. The fresh leaves were washed; sun dried and then kept in an oven at $70^{\circ} \mathrm{C}$ for five days. The dried plant material was ground to a fine powder and stored in a plastic jar to be used as dye for cotton dyeing. Mercerized cotton fabrics used for dyeing with black carrot powder were produced by Noor Fatima Textile Faisalabad.

Extracting natural dye from black carrot plant residue was carried out by boiling a small amount of dye powder, keeping the solid-to-liquor ratio of 1:25. Suitable media are given below.

1 Aqueous medium.
2. Alkaline medium: Potassium hydroxide and sodium hydroxide were used as alkaline medium in the range $1-10 \%$

3. Organic medium: Ethanol and methanol were used in a range of 20, 40, 60, 80 and 100\%. Methanolic $\mathrm{KOH}(1-5 \%)$ was prepared by dissolving $\mathrm{KOH}$ in $100 \%$ methanol.

4. Acidic medium: Hydrochloric acid $(\mathrm{HCl})$, acidified methanol and acidified ethanol were used in a range of $1,2,3,4$ and $5 \%$ (this medium was employed to compare the results with conventional solvents; acidified methanol or ethanol was prepared by dissolving $1-5 \mathrm{ml}$ of conc. $\mathrm{HCl}$ in $99-95 \mathrm{ml}$ of methanol and ethanol).

After boiling, the crude material was filtered and each extract was used for cotton dyeing. The best extraction medium was further used for optimizing and mordanting studies. Dyeing of cotton fabric was carried out by employing $25 \mathrm{ml}$ of respective extract for $1 \mathrm{~g}$ of fabric at $60^{\circ} \mathrm{C}$ for $60 \mathrm{~min}$, keeping the extract-to-fabric ratio of $1: 25$.

Different dyeing parameters such as temperature, time, salt concentration, $\mathrm{pH}$ and material-to-liquor ratio were optimized. In order to achieve optimum dyeing temperature, the dye extract was treated with cotton fabric at varying temperatures, such as $40,50,60,70,80$ and $90^{\circ} \mathrm{C}$ for one hour. Various dyeing times such as $25,35,45,55,65$, 75 and 85 minutes were employed to achieve optimum dyeing time interval. To determine the influence of salt concentration on dyeing behavior of black carrot, varying levels of $\mathrm{NaCl}$ salt (1-10\%) were used. To find out optimum $\mathrm{pH}$ for dyeing,

To improve color strength and color fastness properties of dyed cotton fabrics, pre- and postmordanting were employed at optimum dyeing conditions using black carrot dye extract. Bio mordants, such as turmeric (Curcuma longa L.), henna (Lawsonia inermis L.), pomegranate (Punica granatum L.) rind, golden shower plant (Cassia fistula L.) bark and onion (Allium cepa L.) peel as well as chemical mordants such as tannic acid, copper sulphate, iron sulphate and potassium dichromate were employed. Based on the results, two best chemicals as well as biomordant were selected for further study. For preparing the biomordants, 1-10 $\mathrm{g}$ of respective plant material was boiled separately in water for one hour, filtered and used for further study. Similarly, 1-10\% of metal salt solutions of respective chemical mordants were used.

The color strength values $(\mathrm{K} / \mathrm{S})$ of all dyed fabrics were determined with the help of Spectra flash SF 600 at the Department of Applied Chemistry, Government College University, Faisalabad. Color fastness properties of dyed fabrics were determined using ISO methods such as ISO $105 \mathrm{BO} 2$ for light fastness, ISO105-CO3 for washing fastness and ISO 105 $\mathrm{X}-12$ for rubbing fastness. 


\section{Results and Discussion}

The results given in Tables 1-3 showed that $2 \%$ of acidified methanol was the best medium to obtain maximum colorants from black carrot leftovers. Depending on the colorant polarity, acidified methanolic extract produced a higher value of color strength $(\mathrm{K} / \mathrm{S})$ as compared to aqueous, alkaline or organic media used in the study. The higher level of colorant extraction from black carrot residues in acidified medium indicated that during boiling, this medium helped to transfer more mass kinetics as compared to aqueous or other medium used in the study [31,32]. The concentration of acidified methanol also played a role in isolating the colorant from black carrot residues. The low concentration of acid was not helpful to increase the extraction, while too-high levels mediated the extraction of other phytochemicals along with the desired colorant [33].

The current experimental results indicated that darker color shades of black carrot leftovers extracting treated fabric could be achieved by keeping dyeing bath at $70^{\circ} \mathrm{C}$ as compared with all other temperature regimes applied during the study (Fig. 1). A dyeing time with a duration of 55 minutes was proven to be more useful in creating good color depth of black carrot leftovers extract-treated fabric than those of other time intervals used during current experimentation (Fig. 2). The results given in Fig. 3 also showed that $4.0 \mathrm{~g}$ of salt as an exhausting agent produced good color strength compared with all other salt levels tested during the current investigation, indicating that the appropriate

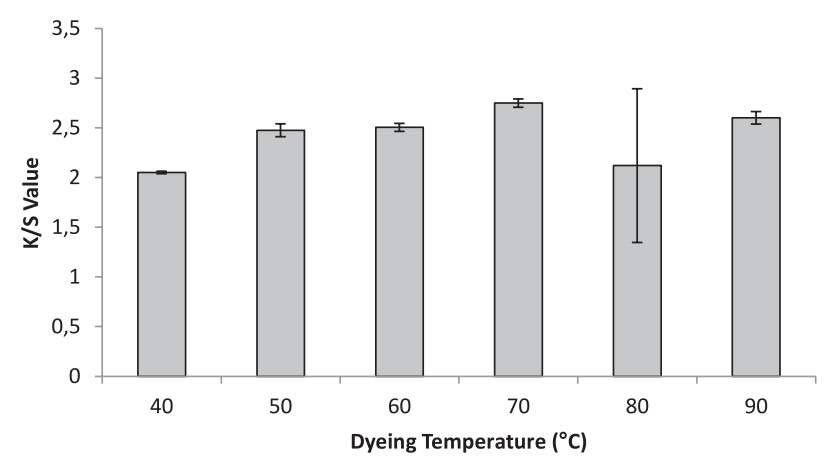

Fig. 1. Effect of varying dyeing temperatures on the color strength of cotton fabrics dyed by using black carrot plant residues (LSD value at $5 \%$ probability level $=0.56$ ).

contact time of dye extract with fabric helped maintain the strike rate of colorant onto fabric. The optimum contact time to raise the kinetic energy of colorant resulted in good $\mathrm{K} / \mathrm{S}$ value [34]. The optimum dyeing interval of 55 minutes to produce darker shades of high $\mathrm{K} / \mathrm{S}$ values as observed during the present investigation revealed the efficacy of black carrot-based colorant to produce darker shades within less time.

The addition of salt during dyeing helped to achieve maximum exhaustion and acceptable color characteristics. This exhausting agent had led the colorant towards fabric with in short range of attractive forces [35]. The higher salt levels, above the optimal amount, may result in over-exhaustion, leading to

Table 1. Effect of varying organic extraction media on the color strength of cotton fabrics dyed with black carrot plant residues.

\begin{tabular}{|c|c|c|c|c|c|c|c|c|c|c|c|c|c|c|c|}
\hline & \multicolumn{15}{|c|}{ Organic media } \\
\hline & \multicolumn{5}{|c|}{ Methanol (\%) } & \multicolumn{5}{|c|}{ Ethanol (\%) } & \multicolumn{5}{|c|}{ Methanolic KOH (\%) } \\
\hline & 20 & 40 & 60 & 80 & 100 & 20 & 40 & 60 & 80 & 100 & 1 & 2 & 3 & 4 & 5 \\
\hline $\begin{array}{l}\text { Color strength } \\
\text { (K/S ) values }\end{array}$ & 1.05 & 1.62 & 1.24 & 2.12 & 2.30 & 1.42 & 3.28 & 3.74 & 2.04 & 2.58 & 2.06 & 1.73 & 1.55 & 1.32 & 1.24 \\
\hline
\end{tabular}

Table 2. Effect of two alkaline extraction media on the color strength of cotton fabrics dyed with black carrot plant residues.

\begin{tabular}{|c|c|c|c|c|c|c|c|c|c|c|c|c|c|c|c|c|c|c|c|}
\hline \multicolumn{20}{|c|}{ Alkaline media } \\
\hline \multicolumn{10}{|c|}{$\mathrm{NaOH}(\%)$} & \multicolumn{10}{|c|}{$\mathrm{KOH}(\%)$} \\
\hline 1 & 2 & 3 & 4 & 5 & 6 & 7 & 8 & 9 & 10 & 1 & 2 & 3 & 4 & 5 & 6 & 7 & 8 & 9 & 10 \\
\hline 2.26 & 2.29 & 2.20 & 1.29 & 1.88 & 2.12 & 1.59 & 1.06 & 0.88 & 0.68 & 1.36 & 1.40 & 1.52 & 1.79 & 1.6 & 1.06 & 1.54 & 1.95 & 1.52 & 1.43 \\
\hline
\end{tabular}

Table 3. Effect of acidic and aqueous extraction media on the color strength of cotton fabrics dyed by using black carrot plant residues.

\begin{tabular}{|c|c|c|c|c|c|c|c|c|c|c|c|c|c|c|c|c|}
\hline & \multicolumn{15}{|c|}{ Acidic media } & \multirow{3}{*}{$\begin{array}{c}\begin{array}{c}\text { Aqueous } \\
\text { medium }\end{array} \\
100 \mathrm{ml}\end{array}$} \\
\hline & \multicolumn{5}{|c|}{$\mathrm{HCl}(\%)$} & \multicolumn{5}{|c|}{ Acidified methanol (\%) } & \multicolumn{5}{|c|}{ Acidified ethanol (\%) } & \\
\hline & 1 & 2 & 3 & 4 & 5 & 1 & 2 & 3 & 4 & 5 & 1 & 2 & 3 & 4 & 5 & \\
\hline $\begin{array}{l}\text { Color strength } \\
(\mathrm{K} / \mathrm{S}) \text { values }\end{array}$ & 1.89 & 1.79 & 1.06 & 0.91 & 1.04 & 3.31 & 4.32 & 2.24 & 3.18 & 2.55 & 2.21 & 2.65 & 2.27 & 0.30 & 0.30 & 1.06 \\
\hline
\end{tabular}




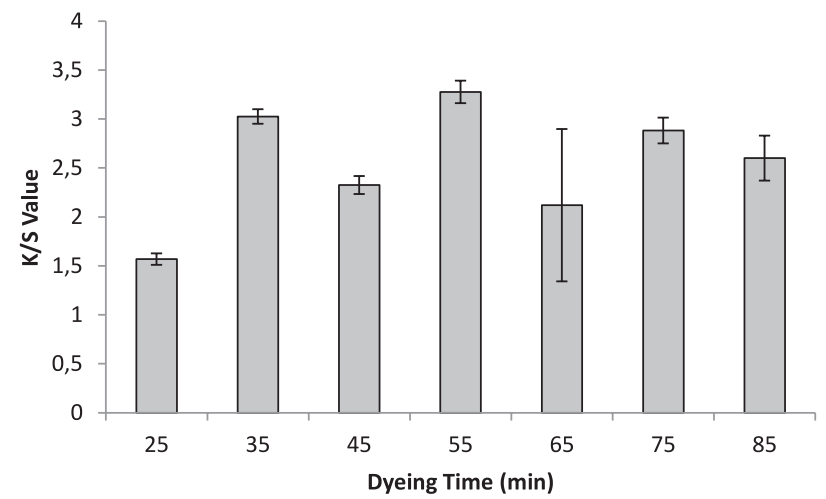

Fig. 2. Effect of varying dyeing times on the color strength of cotton fabrics dyed by using black carrot plant residues (LSD value at $5 \%$ probability level $=0.59$ ).

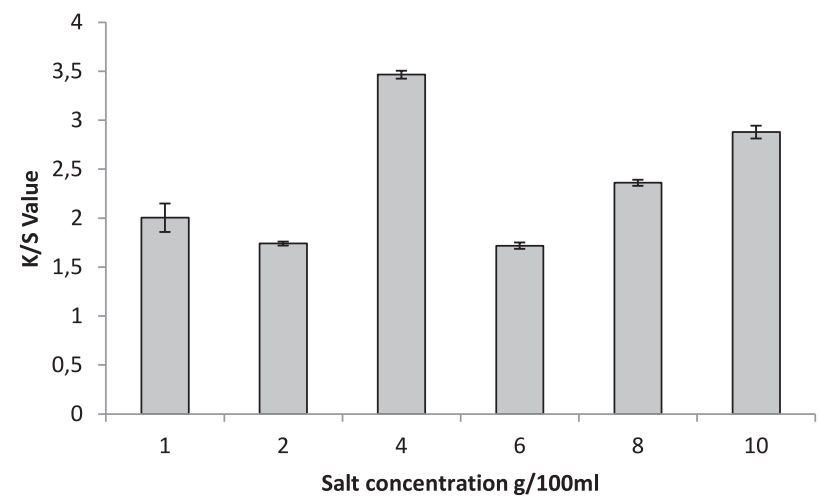

Fig. 3. Effect of varying salt concentrations on the color strength of cotton fabrics dyed using black carrot plant residues (LSD value at $5 \%$ probability level $=0.125$ ).

desorption. Hence good color characteristics were obtained by dyeing cotton fabric at $70^{\circ} \mathrm{C}$ for 55 minutes using $4.0 \mathrm{~g}$ of salt as an exhausting agent.

The dyeing results from mordanting experiments revealed that varying concentrations of chemical mordants produced different shades and variable rating of fastness properties on black carrot leftover-treated cotton fabrics (Table 4). Among different chemical mordants used in the study, tannic acid and iron sulphate produced darker shades than all others. A tannic acid level of $6 \%$ produced darker shades when treated before dying of fabric with black carrot extract compared with all other levels of this mordant used in the study. The treatment of black carrot extract-dyed cotton fabric with tannic acid gave darker shades when this mordant was applied in a concentration of $8 \%$ as compared to all other concentrations. Comparatively, tannic acid post-mordanting showed the highest color strength as compared to pre-mordanting iron sulphate formed stable complexes with dye molecule and cotton fabric and exhibited excellent fastness properties when applied in concentrations of 8 and $2 \%$ as pre- and post-mordanting agent, respectively. The data shown in (Table 4) suggested that color strength and color fastness properties of iron post-mordanting were higher in contrast to pre-mordanting

Based on the results of bio-mordanting experiments, turmeric and henna powder were selected for mordanting of black carrot leaves extract-treated fabric. By employing different concentrations (1-10\%) of two bio mordants, turmeric and henna powder, multiple color strength values were recorded (Table 4). In bio pre-mordanting of cotton fabrics with turmeric powder, $2 \%$ was the optimum concentration, which resulted in higher K/S color strength values. In bio post-mordanting with turmeric, $8 \%$ powder showed higher color strength by the formation of a strong linkage between cotton and dye molecules. The treatment of black carrot leaves extract dyed fabric with $4 \%$ henna powder produced darker shades, whereas, pre-mordanting with $6 \%$ henna powder was more beneficial in producing good color strength (Table 4).

The higher color strength values at optimum concentrations of mordants indicate strong bonds of applied chemicals and fabric. The decreased color strength at other levels might be due to the aggregation of dye molecules and mordant onto cotton fabric, leading to low color strength [34-37]. The concentration of mordant below the optimum level had less affinity to fabric and led to poor color strength values [36-37]. Above optimum mordant concentration, the applied chemical caused unevenness, resulting in low color strength values of dyed fabric.

Dyeing of fabrics with natural colorant along with bio mordanting could be a good alternative to chemical mordanting [38]. The turmeric powder containing coloring component (curcumin) was firmly bound to anthocyanin and formed a strong linkage onto cotton fabric, resulting in a dark yellow color with excellent color strength. More than optimum concentrations of turmeric powder might have caused precipitate formation and showed minimum color strength, while less concentration was insufficient to form a strong bond formation and exhibited low color strength [39]. Henna was another excellent bio mordant that produced excellent color strength $(\mathrm{K} / \mathrm{S})$ on dyed fabric. In premordanting, color strength $(\mathrm{K} / \mathrm{S})$ was increased up to $6 \%$ henna extract, indicating the strong coordination between the colorant (lawsone), anthocyanin and cellulosic fabric. Overall, $4 \%$ henna as post bio mordant showed relatively good color strength properties [40]. The bio mordanting displayed higher $\mathrm{K} / \mathrm{S}$ values in comparison to chemical mordanting and yielded multiple color shades, thereby making the process more eco-friendly and sustainable.

Fastness properties estimation results revealed that 6 or $8 \%$ of tannic acid and iron sulphate produced excellent rating of fastness (Table 4). This was because the iron having low reduction potential formed good metal dye complex onto fabric before or after dyeing, whereas tannic acid via H-bonding produced a strong shade [11]. Similarly, bio-mordants produced excellent 


\begin{tabular}{|c|c|c|c|c|c|c|c|c|c|c|c|c|c|c|c|}
\hline \multirow{10}{*}{\multicolumn{2}{|c|}{ 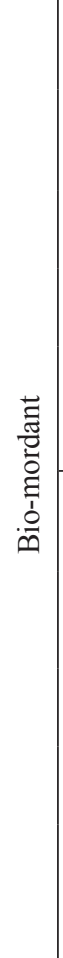 }} & & $\frac{\sqrt{2}}{3}$ & $\stackrel{+}{m}$ & $\frac{t}{m}$ & $\theta$ & $\stackrel{n}{\gamma}$ & + & $\stackrel{n}{\gamma}$ & $\nabla$ & $\stackrel{t}{m}$ & $\stackrel{\Re}{f}$ & $\sigma$ & $\stackrel{n}{\gamma}$ & $\nabla$ \\
\hline & & & 瓷 & $m$ & $\stackrel{\wp}{f}$ & $\stackrel{n}{\gamma}$ & $\stackrel{n}{\gamma}$ & $\frac{t}{m}$ & $\nabla$ & $\stackrel{n}{\gamma}$ & $\nabla$ & $\nabla$ & $\nabla$ & $\nabla$ & $\stackrel{n}{f}$ \\
\hline & & 苛 & $\sum_{3}^{1}$ & $\underset{m}{+}$ & $n$ & $n$ & $\nabla$ & $\nabla$ & $\frac{+}{m}$ & $\nabla$ & $\nabla$ & $\nabla$ & $\nabla$ & $\frac{t}{m}$ & $m$ \\
\hline & & & 岃 & $m$ & $m$ & 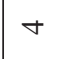 & $\stackrel{n}{f}$ & $m$ & $\nabla$ & $m$ & $\nabla$ & $\stackrel{\curvearrowleft}{f}$ & $\frac{+}{m}$ & $m$ & $n$ \\
\hline & & & $\stackrel{\infty}{\Sigma}$ & 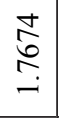 & $\begin{array}{l}\vec{p} \\
\stackrel{\sigma}{-}\end{array}$ & 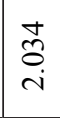 & $\begin{array}{l}\overrightarrow{\vec{a}} \\
\vec{i}\end{array}$ & 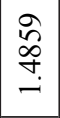 & $\stackrel{\mathcal{F}}{\stackrel{\sim}{m}}$ & $\begin{array}{l}\infty \\
\stackrel{0}{0} \\
\stackrel{0}{n} \\
i \\
ن\end{array}$ & 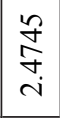 & 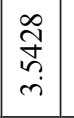 & $\mid \begin{array}{c}\infty \\
\hat{2} \\
\alpha \\
- \\
-\end{array}$ & 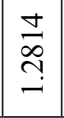 & $\begin{array}{l}\stackrel{2}{2} \\
\stackrel{2}{2} \\
\stackrel{2}{-2}\end{array}$ \\
\hline & & & $\begin{array}{l}\frac{1}{2} \\
3\end{array}$ & $\underset{m}{t}$ & $m$ & 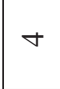 & $\nabla$ & $\nabla$ & $\stackrel{n}{\gamma}$ & $\stackrel{n}{f}$ & $\nabla$ & 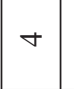 & $\stackrel{n}{f}$ & $\nabla$ & $\nabla$ \\
\hline & & & 訔 & $m$ & $\nabla$ & $\stackrel{n}{f}$ & $\nabla$ & $\stackrel{\curvearrowleft}{\gamma}$ & in & $\frac{d}{m}$ & $\stackrel{n}{\gamma}$ & $\stackrel{n}{\gamma}$ & $\stackrel{n}{\gamma}$ & $\stackrel{n}{\gamma}$ & $\stackrel{n}{f}$ \\
\hline & & $\begin{array}{l}\overrightarrow{\mathrm{v}} \\
\text { 品 }\end{array}$ & $\frac{1}{3}$ & $\underset{m}{+}$ & $\stackrel{\curvearrowleft}{\gtrless}$ & $\sigma$ & $\stackrel{\curvearrowleft}{\gamma}$ & $\nabla$ & $\stackrel{\curvearrowleft}{f}$ & $\nabla$ & $\nabla$ & $\frac{\mathrm{d}}{\mathrm{m}}$ & $\frac{n}{\gamma}$ & $\nabla$ & $\sigma$ \\
\hline & & & 出 & $m$ & $\stackrel{\wp}{f}$ & $\stackrel{n}{f}$ & $\stackrel{\curvearrowleft}{f}$ & $\nabla$ & $\stackrel{n}{f}$ & $m$ & $\nabla$ & $\nabla$ & $\nabla$ & $\stackrel{n}{f}$ & $\frac{ \pm}{m}$ \\
\hline & & & $\stackrel{\infty}{a}$ & 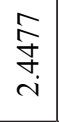 & 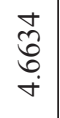 & $\begin{array}{l}\infty \\
\stackrel{\sim}{\sim} \\
\stackrel{+}{+}\end{array}$ & \begin{tabular}{l}
$\stackrel{\infty}{0}$ \\
\multirow{\sim}{+}{} \\
+
\end{tabular} & $\underset{r}{\stackrel{f}{f}}$ & $\begin{array}{l}\stackrel{\bullet}{\circ} \\
\stackrel{\leftrightarrow}{+} \\
\stackrel{+}{+} \\
\end{array}$ & $\begin{array}{l}\hat{\infty} \\
\infty \\
\infty \\
-\end{array}$ & \begin{tabular}{l}
0 \\
\multirow{0}{0}{} \\
$\stackrel{\infty}{-}$ \\
-
\end{tabular} & $\begin{array}{l}\hat{\widehat{b}} \\
0 \\
i\end{array}$ & 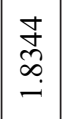 & 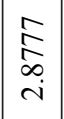 & $\begin{array}{l}0 \\
0 \\
0 \\
0 \\
i \\
i\end{array}$ \\
\hline \multirow{10}{*}{\multicolumn{2}{|c|}{ 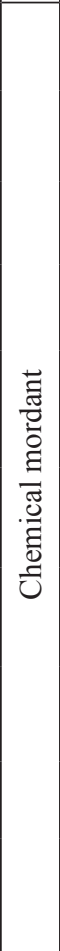 }} & \multirow{5}{*}{ 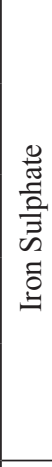 } & $\begin{array}{l}\frac{\pi}{3} \\
3\end{array}$ & + & + & $\frac{m}{m}$ & $\frac{ \pm}{m}$ & $\nabla$ & $\nabla$ & $m$ & $\stackrel{n}{f}$ & 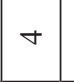 & $\frac{+}{m}$ & $\nabla$ & 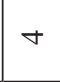 \\
\hline & & & 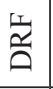 & $\stackrel{+}{m}$ & $\stackrel{ \pm}{m}$ & $\frac{ \pm}{m}$ & $m$ & $\nabla$ & $m$ & $\frac{\Delta}{m}$ & in & $\stackrel{n}{f}$ & $m$ & $\nabla$ & $\stackrel{n}{f}$ \\
\hline & & & 3 & $\nabla$ & $m$ & $m$ & $\frac{ \pm}{m}$ & 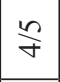 & $\frac{ \pm}{m}$ & $\frac{\mathrm{t}}{m}$ & $\nabla$ & $\frac{+}{m}$ & $\sigma$ & $\stackrel{\curvearrowleft}{f}$ & 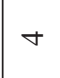 \\
\hline & & & 出 & $m$ & $\stackrel{+}{m}$ & n & $n$ & $\nabla$ & $m$ & m & $\nabla$ & n & $m$ & $\frac{t}{m}$ & m \\
\hline & & & $\stackrel{\infty}{\Sigma}$ & $\begin{array}{l}\curvearrowleft \\
\stackrel{2}{0} \\
0\end{array}$ & $\begin{array}{l}\stackrel{2}{\$} \\
\stackrel{0}{0}\end{array}$ & 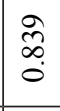 & $\begin{array}{l}m \\
\hat{0} \\
\stackrel{0}{0}\end{array}$ & 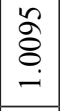 & \begin{tabular}{|c|}
\multirow{2}{*}{} \\
$\hat{\infty}$ \\
0 \\
0 \\
\end{tabular} & \begin{tabular}{l}
\multirow{7}{*}{} \\
$\infty$ \\
0 \\
0
\end{tabular} & 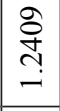 & \begin{tabular}{|l|}
$\vec{J}$ \\
\\
\\
\end{tabular} & \begin{tabular}{|c|}
$\infty$ \\
\multirow{+}{+}{} \\
$\infty$ \\
0 \\
0
\end{tabular} & $\frac{\hat{\sigma}}{\sigma}$ & $\begin{array}{l}0 \\
\stackrel{\infty}{\infty} \\
\stackrel{0}{0} \\
\end{array}$ \\
\hline & & & $\begin{array}{l}\frac{1}{2} \\
3\end{array}$ & $\stackrel{n}{f}$ & $m$ & t & $\stackrel{n}{\gamma}$ & $\nabla$ & $\stackrel{n}{\gamma}$ & $\mathrm{m}^{+}$ & $\nabla$ & $\frac{n}{\gamma}$ & $\theta$ & $\frac{n}{\gamma}$ & $\frac{t}{m}$ \\
\hline & & & $\frac{\sqrt{n}}{a}$ & $\stackrel{\curvearrowleft}{f}$ & $m$ & $\stackrel{n}{f}$ & $\stackrel{n}{f}$ & $\stackrel{n}{f}$ & in & $\nabla$ & $\nabla$ & $\frac{n}{f}$ & $\sigma$ & in & $m$ \\
\hline & & 芯 & $\frac{1}{3}$ & 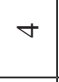 & $m$ & $\theta$ & $\stackrel{\curvearrowleft}{f}$ & $\stackrel{n}{\gamma}$ & $\stackrel{\curvearrowleft}{f}$ & $\frac{t}{m}$ & 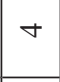 & + & $\stackrel{n}{f}$ & $\stackrel{n}{f}$ & $\sigma$ \\
\hline & & & 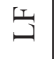 & $\nabla$ & $n$ & $\sigma$ & $\stackrel{n}{f}$ & + & in & $m$ & $\nabla$ & $\theta$ & $\frac{n}{f}$ & $\stackrel{n}{f}$ & $m$ \\
\hline & & & $\Sigma$ & 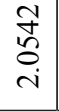 & 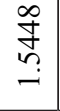 & 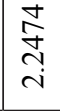 & $\begin{array}{l}\infty \\
\infty \\
\stackrel{\infty}{\oplus} \\
\stackrel{n}{+}\end{array}$ & $\begin{array}{l}\hat{B} \\
\stackrel{\sim}{7} \\
i \\
i\end{array}$ & 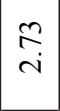 & $\frac{\hat{n}}{\mathfrak{m}}$ & & $\begin{array}{l}\stackrel{0}{0} \\
\stackrel{7}{+} \\
i\end{array}$ & 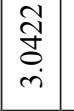 & 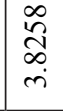 & 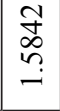 \\
\hline & & 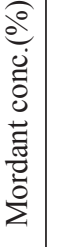 & & - & $\sim$ & 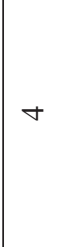 & 0 & $\infty$ & 으 & - & 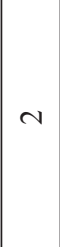 & 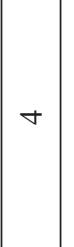 & 0 & $\infty$ & 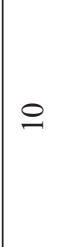 \\
\hline & 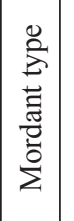 & & & & . & & & & & & & 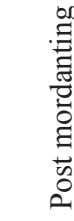 & 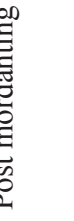 & & \\
\hline
\end{tabular}


results for fastness properties. The conjugation sites present in functional moiety of bio mordant (curcumin from turmeric and lawsone from henna) formed extra $\mathrm{H}$-bond with $-\mathrm{OH}$ of colorant and $-\mathrm{OH}$ of cellulosic fabric, thus producing a stronger shade as compared to metal dye complex [41]. Upon treatment of mordanted fabrics to heat, light, and washing, a high rating was observed.

\section{Conclusion}

Black carrot plant residues could be an ecofriendly and cost-effective natural dye source for textile dyeing. The optimized dyeing parameters were $70^{\circ} \mathrm{C}$ temperature, 55 minutes dyeing time and $4.0 \mathrm{~g} \mathrm{NaCl}$ salt as exhausting agent. In the case of chemical mordanting, $6 \%$ tannic acid and $8 \%$ iron sulphate as pre-mordant and $8 \%$ tannic acid and $2 \%$ iron sulphate as post-mordant showed maximum color strength values. Bio mordanting experiments revealed that $2 \%$ turmeric and $6 \%$ henna as pre-mordant as well as $8 \%$ turmeric and $4 \%$ henna as post-mordant showed maximum color strength values. Mordanted cotton fabrics showed best color fastness properties in terms of light, washing dry and wetrubbing fastness

\section{Acknowledgments}

We are thankful to Mr. Zafar Iqbal Manager QA \& QC Lab Noor Fatima Fabrics Faisalabad, Pakistan and to Mr. Muhammad Abbas Executive director Harris Dyes \& Chemical Faisalabad for providing us technical guidance to conduct a part of Ph.D studies

\section{Conflict of Interest}

The authors declare no conflict of interest.

\section{References}

1. SINGH R., SRIVASTAVA S. Exploration of flower based natural dyes, a review. Res. J. Recent Sci. 4, 6, 2015.

2. JAMADAR D., SANNAPAPAMMA K.J. Acacia nilotica Pods: A Natural Dye Source for Textile Colouration. Int. J. Curr. Microbiol. App. Sci. 7, 602, 2018.

3. KASIRI M.B., SAFAPOUR S. Exploring and exploiting plants extracts as the natural dyes/antimicrobials in textiles processing. Prog. Color Colorants Coat. 8, 87, 2015.

4. BAAKA N., HADDAR W., BEN TICHA M., AMORIM, M.T.P., M'HENNI M.F. Sustainability issues of ultrasonic wool dyeing with grape pomace colourant. Nat. Prod. Res. 32, 1655, 2017.

5. YIN Y., JIA J., WANG T., WANG C. Optimization of natural anthocyanin efficient extracting from purple sweet potato for silk fabric dyeing. J. Clean. Prod. 149, 673, 2017.

6. SAMANTA K., SAMANTA P., SINGHEE D. Fundamentals of Natural Dyeing of Textiles: Pros and
Cons. Curr. Trends Fashion Technol. Textile Eng. 2, 001, 2018.

7. MIAH M.R., TELEGIN F.Y., MIAH M.S., SHAHID M.A., RAHMAN M.S., RAN J. Comparative Analysis of Colour Strength and Fastness Properties on Extracts Natural Dye from Onion's Outer Shell and Its Use in Eco-friendly Dyeing of Silk Fabric. Int. J. Photochem. Photobiol. 2, 1, 2017.

8. AGNHAGE T., PERWUELZ A., BEHARY N. Towards sustainable Rubia tinctorum L. dyeing of woven fabric: how life cycle assessment can contribute. J. Clean. Prod. 141, 1221, 2017.

9. BHUIYAN M.A.R., ALI A., ISLAM A., HANNAN M.A., KABIR S.M.F., ISLAM M.N. Coloration of polyester fiber with natural dye henna (Lawsonia inermis L.) without using mordant: a new approach towards a cleaner production. Fash. Text. 5:2, 1, 2018.

10. MONGKHOLRATTANASIT R., SAIWAN C., RUNGRUANGKITKRAI N., PUNRATTANASIN N., SRIHARUKSA K., KLAICHOI C., NAKPATHOM M. Eco-Dyeing of Silk Fabric with Garcinia Dulcis (Roxb.) Kurz Bark as a Source of Natural Dye by using The Padding Technique. J. Nat. Fibers. 13, 65, 2016.

11. ADEEL S., ZUBER M., ZIA K.M. Microwave-assisted extraction and dyeing of chemical and bio-mordanted cotton fabric using harmal seeds as a source of natural dye. Environ. Sci. Pollut. Res. 25, 11100, 2018.

12. SINGH, L., SINGH R., MOIRANGTHEM N. Natural dyes Prospects for entrepreneurship, Int. J. Chem. Nat. Sci. 3, 249, 2015.

13. POULIN J.A New Methodology for the Characterisation of Natural Dyes on Museum Objects Using Gas Chromatography - Mass Spectrometry. Stud. Conserv. 63, 36, 2018.

14. ZUBAIRU A., MSHELIA Y.M. Effects of Selected Mordants on the Application of Natural Dye from Onion Skin (Allium cepa). Sci. Technol. 5, 26, 2015.

15. ALI S., NOOR S., SIDDIQUA U.H., JABEEN S., HUSSAIN T. Central Composite Design Approach for Optimization of Extraction and Dyeing Conditions of Marigold Colorant. Nat. Prod. Chem. Res. 4, 1, 2016.

16. KULKARNI S.S., BODAKE U.M., PATHADE G.R. Extraction of Natural Dye from Chili (Capsicum Annum) for Textile Coloration. Univers. J. Environ. Res. Tech. 1, 58, 2011.

17. TESFAYE T., BEGAM R., SITHOLE B.B., SHABARIDHARAN K. Dyeing Cotton with Dyes Extracted from Eucalyptus and Mango Trees. Int. J. Sci. Technol. 3, 310, 2015.

18. BATOOL F., ADEEL S., AZEEM M., KHAN A.A., BHATTI I.A., GHAFFAR A., IQBAL N. Gamma radiations induced improvement in dyeing properties and colorfastness of cotton fabrics dyed with chicken gizzard leaves extracts. Radiat. Phys. Chem. 89, 33, 2013.

19. KHAN A.A., IQBAL N., ADEEL S., AZEEM M., BATOOL F., BHATTI I.A. Extraction of natural dye from red calico leaves: Gamma ray assisted improvements in colour strength and fastness properties. Dyes Pigments. 103, 50, 2014

20. AJMAL M., ADEEL S., AZEEM M., ZUBER M., AKHTAR N., IQBAL N. Modulation of pomegranate peel colourant characteristics for textile dyeing using high energy radiations. Ind Crops Prod. 58, 188, 2014.

21. XU Y., ZHU X., CHEN Y., GONG Y., LIU L., Expression profiling of genes involved in ascorbate biosynthesis 
and recycling during fleshy root development in radish. Plant Physiol. Biochem. 70, 269, 2013.

22. CHATATIKUN M., CHIABCHALARD A. Phytochemical screening and free radical scavenging activities of orange baby carrot and carrot (Daucus carota Linn.) root crude extracts. J. Chem. Pharm. Res. 5, 97, 2013.

23. LEITE C.W., BOROSKI M., BOEING, J.S., AGUIAR A.C., FRANÇA P.B., SOUZA N.E.D., VISENTAINER J.V. Chemical characterization of leaves of organically grown carrot (Dacus carota L.) in various stages of development for use as food. Food Sci. Technol. 31, 735, 2011.

24. MONTILLA E.C., ARZABA M.R., HILLEBRAND S., WINTERHALTER P. Anthocyanin composition of black carrot (Daucus carota ssp. sativus var. atrorubens Alef.) cultivars Antonina, Beta Sweet, Deep Purple, and Purple Haze. J. Agric. Food Chem. 59, 3385, 2011.

25. SHUKLA D., VANKAR P.S. Natural dyeing with black carrot: New source for newer shades on silk. J. Nat. Fibers. 10, 207, 2013.

26. XIANLI W., ROLAND L.P. Identification and characterization of anthocyanin by high performance liquid chromatography-electrospray ionization tandem mass spectrometry in common foods in United States: vegetables, nut and grains. J. Agric. Food. Chem. 53, 3101, 2005.

27. ASSOUS M.T.M., ABDEL-HADY M.M., MEDANY G.M. Evaluation of red pigment extracted from purple carrots and its utilization as antioxidant and natural food colorants. Ann. Agric. Sci. 59, 1, 2014.

28. GIZIR A.M., TURKER N., ARTUVAN E. Pressurized acidified water extraction of black carrot (Daucus carota ssp. sativus var. atrorubens Alef.) anthocyanins. Eur. Food Res. Technol. 226, 363, 2008.

29. SINGH K., SINGH N., CHANDY A., Manigauha A. In vivo antioxidant and hepatoprotective activity of methanolic extracts of Daucus carota seeds in experimental animals. Asian. Pac. J. Trop. Biomed. 2, 385. 2012.

30. RAJAGOPAL P.L., SREEJITH K.R., PREMALETHA K. Natural colorants as safe additives: A review. Worldwide J. Multidisciplinary Res. Develop. 2, 28, 2016.

31. PATEL B.H., AGARWAL B.J., PATEL H.M. Novel padding technique for dyeing babool dye on cotton. Colourage. 50, 21, 2003.
32. HEBA F.M., GAMAL A.M. Environmental Assessment of Osage Orange extraction and its dyeing properties on protein fabrics, Part 1. Standardization of extraction. J. Environ. Sci. Tech. 4, 395, 2011.

33. BIESAGA M., PYRZYNSKA K. Stability of bioactive polyphenols from honey during different extraction methods. Food Chem. 136, 46, 2013.

34. ADEEL S., BHATTI I.A., KAUSAR A., OSMAN E. Influence of UV radiations on the extraction and dyeing of cotton fabric with Curcuma longa L. Ind. J. Fibre Text. Res. 37, 87, 2012.

35. VELMURUGAN P., SHIM J., SEO S., OH B. Extraction of natural dye from Coreopsis tinctoria flower petals for leather dyeing-an eco-friendly approach. Fiber Polym. 17, 1875, 2016.

36. MONGKHOLRATTANASIT R., PUNRATTANASIN N. Properties of silk fabric dyed with eucaliptus, quercetin, rutin and tannin using padding techniques. Bangkok, Thailand: RMUTP International Conference on Textiles \& Fashion, 456, 2012.

37. MAHMOOD S., ALI S., QAMAR M.A., ASHRAF M.R., ATIF M., IQBAL M., HUSSAIN, T. Hard water and dyeing properties effect of pre-and post-mordanting on dyeing using Eucalyptus globulus and Curcuma longa extracts. Pol. J. Environ. Stud. 26, 747, 2017.

38. HUSSAAN M., IQBAL N., ADEEL S., AZEEM M., JAVED M.T., RAZA A. Microwave-assisted enhancement of milkweed (Calotropis procera L.) leaves as an ecofriendly source of natural colorants for textile. Environ. Sci. Pollut. Res. 24, 5089, 2017.

39. HASAN M.M., HOSSAIN M. B., ANWARUL AZIM A.Y.M., GHOSH N.C., REZA M.S. Application of purified curcumin as natural dye on cotton and polyester. Int. J. Eng. Technol. 14, 17, 2014.

40. KANNANMARIKANI, KANNAN, U.S., KANNIAPPAN R. Assessment of dyeing properties and quality parameters of natural dye extracted from Lawsonia inermis. Euro J. Exp. Biol. 5, 62, 2015.

41. ADEEL S., ZIA K. M., ABDULLAH M., REHMAN F. U., SALMAN M., \& ZUBER M. Ultrasonic assisted improved extraction and dyeing of mordanted silk fabric using neem bark as source of natural colorant. Nat. Prod. Res. 1, 2018. 
